\title{
Developing a national competency-based curriculum for technical nurses in Egypt
}

Sharon M. Brownie, ${ }^{1,2,3}$ Charles Docherty, ${ }^{4}$ Nabeel Al-Yateem, ${ }^{5,8}$ Mohamed H. Gadallah, ${ }^{6,7}$ and Rachel Rossiter ${ }^{8}$

${ }^{1}$ School of Nursing \& Midwifery, Aga Khan University, Nairobi, East Africa (Correspondence to: S.M. Brownie: sharon.brownie@aku.edu). ²School of Medicine, Griffith Health, Griffith University, Gold Coast, QLD, Australia. 3Oxford PRAXIS Forum, Green Templeton College, Oxford University, United Kingdom. ${ }^{4}$ Centre for Innovation in Medical Education, Aga Khan University, Karachi, Pakistan. ${ }^{5}$ Department of Nursing, University of Sharjah, Sharjah, United Arab Emirates. ${ }^{6}$ Education Development Fund (EDF), the Egyptian Cabinet of Ministers, Cairo, Egypt. ${ }^{7}$ Industrial Engineering \& Operations Research, Faculty of Engineering, Cairo University, Egypt. ${ }^{8}$ School of Nursing, Midwifery \& Indigenous Health, Charles Sturt University, Sydney, Australia.

\begin{abstract}
Nursing in Egypt has evolved over recent decades. Development has accelerated following recent government recognition of the contribution nurses make to healthcare access, quality and delivery. A vision to enhance nursing capacity resulted in a recent mandate requiring all nursing curricula to be competency based. Concurrently, the Educational Development Fund of the Egyptian Cabinet of Ministers drafted a nursing educational plan including a strategy to develop and implement a contextually congruent educational model with proven success comparable to international standards. This report discusses the 4-year curriculum development project designed to upgrade the current technical-level nursing curriculum to a consistent competency-based model. The competency-based educational model will be trialled in 3 technical institutes before nationwide rollout and implementation. Details of the project plan are described, including an overview of curriculum development considerations. This report provides insights for policy-makers and educators embarking on similar health workforce reform and capacity development initiatives.
\end{abstract}

Keywords: nursing education, curriculum development, institutes and academies, capacity building, Egypt

Citation: Brownie SM; Docherty C; Al-Yateem N; Gadallah MH; Rossiter R. Developing a national competency-based curriculum for technical nurses in Egypt. East Mediterr Health J. 2018;24(9):922-932. https://doi.org/10.26719/2018.24.9.922

Received: 29/09/17; accepted: 17/04/18

Copyright (c) World Health Organization (WHO) 2018. Some rights reserved. This work is available under the CC BY-NC-SA 3.o IGO license (https:// creativecommons.org/licenses/by-nc-sa/3.o/igo).

\section{Introduction}

The population of Egypt was estimated to be $>95.5$ million in August 2017 (1), distributed across 27 governorates, with $60 \%$ resident in rural areas. World Health Organization (WHO) data indicate that $25.2 \%$ of the population were under the international poverty line in 2015 (2). Improved health service and workforce capacity is a priority for the Egyptian Government. Representatives of the Technical Institutes Directorate of the Egyptian Ministry of Health and Population (MoHP) and the Educational Development Fund (EDF) of the Egyptian Cabinet of Ministers have confirmed the essential role of nurses in Egypt, and focused on strengthening nursing workforce capacity through reforming the nursing education system. Current plans for a new national curriculum represent an initial step in workforce reform and capacity development. The project detailed in this manuscript outlines the EDF plan to develop a national competency-based curriculum $(\mathrm{CBC})$ prototype for technical or second-level nurses in Egypt qualifying under the National Technical Institute system.

\section{Definitions of first- and second-level nurses}

The role and scope of practice for first- and second-level nurses is usually defined by the level of the educational programme including: hours of embedded practical ex- perience, geographical jurisdiction, professional regulation, legislation, and local health service policies $(3,4)$. Currently, there, is no globally clear definition of a firstor second-level nurse and terminology differs across nations. Titles of second-level nurses range from technical nurses in Egypt (5) to enrolled nurses in Australia and New Zealand (6), practical nurses in the United Arab Emirates (UAE) (7) and associate degree nurses in the United States of America (USA) (4). Despite differences in nomenclature, there are some common global features delineating first- and second-level nurses, as outlined in the following examples. 1) Length of training: second-level nurses typically complete a 2 -year training programme that may include a 6-month internship. A qualification is issued at either certificate or diploma level. First-level nurses usually complete a 3-4-year training programme culminating in a degree-level qualification. 2) Scope of practice: second-level nurses typically work in roles closely aligned to bedside/direct patient care (3), practicing under the supervision of first-level nurses. 3) Educational context: second-level nurses are typically prepared in programmes governed by the vocational rather than the higher education sector. Therefore, programmes are typically delivered from vocationally orientated technical institutes, community colleges or trade schools rather than higher education formally accredited universities.

The project described here is based on the vocational or technical education sector in Egypt; in particular, in 
the technical institutes that constitute a major vehicle for the delivery of technical-level education for secondlevel nurses. Although preparation of second-level nurses also occurs in the Egyptian university sector, this initial government-initiated project focuses on curriculum reform in the 12 technical institutes currently engaged in preparation of technical-level nurses.

\section{Nursing in Egypt}

Egypt has a chronic nursing shortage. In 2015, there were 14.8 nurses and midwives for every 10000 Egyptians (2). This shortage, attributed to current working conditions and migration of skilled nurses, negatively affects patient outcomes. Other issues include insufficient resources and funding, maldistribution of nurses geographically and across health services, and a poor public perception of the profession (8). A 2012 report of the MoHP estimated that Egypt needs around 44000 more nurses for the nation (9). Regrettably, Egyptian nursing workforce density levels are declining as per the predicted trend for Africa and Middle Eastern nations to 2030. Density levels in 2004 were reported as 1.994 per 1000 population, and dropped over a decade to 1.434 per 1000 in 2014; only half of the global average of 2.92 nurses per $1000(10,11)$.

Challenges for both nursing education and the creation of a positive inflow to nursing workforce numbers include under-resourcing, lack of practical training opportunities and outdated curricula (11). Upgraded nursing curricula models will enhance the capacity of the profession and better position nurses as key drivers of health advances (12). The vision and strategy of aligning Egyptian health needs in the 21st century with enhanced capacity of the nursing education system will enable Egypt to make progress with identified health indicators (13).

\section{Nursing education in Egypt}

Entry to the nursing profession follows different pathways with programmes governed by two separate government ministries, namely the MoHP and the Ministry of Higher Education (MoHE). Programmes governed by the MoHP include the technical secondary schools of nursing, which students enter while still completing high school, and the practical nursing programmes within the technical institutes in the vocational education sector. Programmes governed by the MoHE and Nursing Sector Group of the Supreme Council of Universities are for graduate degree-level nurses and above, although technical-level nurses are also educated in the university sector (9). The current system supports entry to the nursing profession at three levels: diplomas from secondary schools of nursing, diplomas via technical institutes and/or universities, and degrees via the university sector (14). The government of Egypt is leading aligned, but different, nursing education upgrades across the university and vocational education systems, with a view to strengthening both the health workforce and health systems. The government's vision is to ensure that the curriculum under which technical nurses are prepared is competency based and contextually congruent with the health services needs of 21st century Egypt and its people. Simultaneously, the government is progressing degree-level nursing curricula to nationally defined competency-based standards. This work is occurring under the auspices of MoHE and Nursing Sector Group of the Supreme Council of Universities. The National Authority for Quality Assurance and Accreditation of Education (NAQAAE) provides coordinating oversight and holds the accreditation authority to ensure appropriate alignment of the various nursing cadres.

\section{Contextualizing curricula in response to public health challenges in Egypt}

Contextualizing a curriculum to locally specific population health and health systems challenges is an essential component of preparing graduates that are best suited to practice in the local environment. The Egyptian healthcare system is diverse, with a mix of public and private providers. A recent assessment confirmed the achievement of social justice (equal access to liberties, rights and opportunities) and fair universal health service coverage as central to improved health outcomes for vulnerable populations and acceptable levels of patient satisfaction (15). Challenges facing the Egyptian healthcare system include poor maternal and child health services (especially with regard to maternal and child mortality); high rates of violence against children; high rates of disease (noncommunicable, lifestyle-related, and infectious diseases); hospital safety issues; and limited responsiveness to disadvantaged populations $(15,16)$.

Despite recent improvement, maternal and infant mortality rates in Egypt remain high (15,17), with 33 maternal deaths per 100 ooo live births, and 20 infant deaths per 1000 live births in 2015 (2). Although these rates are better than in many poor neighbouring African countries, they do not reflect Egyptian aspirations for healthcare services. In addition, $21.4 \%$ of Egyptian children aged $<5$ years are stunted and $8.4 \%$ are wasted (2). Violence against children is another concern, with a recent report indicating around two thirds of children in Cairo, Alexandria and Assiut had experienced physical violence in the past year and $78 \%$ had experienced emotional violence (16).

Egypt has the highest rate of hepatitis $C$ worldwide (18). In 2008 , an estimated $14.7 \%$ of the population had been infected, with rates higher in Upper Egypt $(28 \%)$ and around 170000 new cases each year (18). Preventing iatrogenic spread of the disease is a significant challenge from the perspective of health professional education, health service delivery and overall public health management. Large-scale progression of hepatitis $C$ to diseases such as cirrhosis and hepatocellular carcinoma adversely affects life expectancy and places undue strain on factors such as population employability, quality of life and cost of health service delivery. A large proportion of hepatitis $C$ infection is iatrogenic, with major contributing factors being hospital/patient safety issues such as poor infection control and equipment sterilization procedures (18). A 2009 study of prevalence of 
adverse events in developing countries found that up to $18 \%$ of hospital admissions in the Eastern Mediterranean Region were associated with patient harm resulting from medical interventions (19). Healthcare-associated infections are common adverse events in developing countries, with increased risk in acute/intensive settings (20). Egypt also has high rates of work-related infections (e.g., hepatitis B) among health workers resulting from sharps injuries (21). These adverse events may be preventable in $48 \%$ of cases (22), with increased attention to safe practices and international patient safety goals (e.g., hand hygiene) a mitigating priority. Patient safety is central to quality healthcare, but this is a major challenge in the Egyptian context; therefore, inclusion of principles of infection control is essential in every module of the developing curriculum. Although treatment for hepatitis $\mathrm{C}$ is now available, it is largely unaffordable for most of the currently infected communities in Egypt (18).

Leading causes of adult mortality in Egypt include ischemic heart disease and stroke (17). Rates of lifestyleassociated health problems are increasing, with the prevalence of risk factors such as obesity and smoking being significantly higher than averages in the Region (17). Access to healthcare in Egypt remains inequitable, with health challenges disproportionally affecting poor people, children and women (16). In particular, there are gaps between rural and urban populations and different regions (23). Upgrading the national nursing education standards and curriculum is important in addressing these issues. Inclusion of contextually relevant themes in the curriculum is particularly important, with priority required in the development of nursing competencies related to health prevention, health promotion, primary healthcare, maternal and child health, patient safety, infection control, and prevention and management of noncommunicable diseases.

\section{Mandate for change}

The Egyptian Constitution (January 2014, Article 18) states that, "Every citizen is entitled to health and to comprehensive health care with quality criteria" (24). To realise this right to health, the healthcare system must be upgraded to respond to population health and health workforce challenges. A key enabler is strengthening nursing education and workforce capacity to enhance the capacity of the profession to respond to Egyptian-specific health priorities.

\section{Project methodology}

The curriculum upgrade project arises from agreement between the MoHP Technical Institutes Directorate and the Egyptian Cabinet of Ministers via the EDF, who have been mandated to design and deliver the project. The EDF vision is to develop "innovative educational models at school and technical education levels with high quality to satisfy market needs" (25). The aligned mission is to develop and implement educational prototype models with proven success comparable with international standards. This EDF-led project will upgrade the national curricula for various national education programmes, including the 2-year Diploma in Nursing for technical-level nurses.

The planning approach is ambitious, but incrementally pragmatic. Progressive enhancements have occurred over recent years; for example, the nowenacted introduction of the minimum of 12 years of general education as a prerequisite entry requirement for nursing, with more changes scheduled in the future (26). Further development plans include a move from older-style curricula to $\mathrm{CBCs}$ for higher education and vocational/technical education-level programmes, requiring rigor and expertise in development. The project is based on a mutual agreement between the EDF and MOHP to develop and upgrade nursing education across the 12 nursing institutes in Egypt (Figure 1).

The vision of the Egyptian government, as translated to the project development team, is to undertake a process of technical-level curriculum reform that will strengthen nursing education and ensure that graduating nurses are prepared with the competencies to have an effective impact on the aforementioned population health challenges.

\section{External expertise}

Following an invitation from the EDF, the Aga Khan University (AKU) (27) responded to provide expert guidance on how to develop a $\mathrm{CBC}$ and transition to competency-based education (CBE). AKU is an entity within the Aga Khan Development Network, which has a long-standing history in capacity development support in Egypt. AKU drew together a team of four nursing education experts with experience and skill sets best suited to supporting existing in-country efforts. The team was chosen based on their collective experience in living and working in in the Middle East and North Africa; proven experience and publication in competency-based nursing education; and current active engagement in senior nursing education roles. Inclusion of an Arabic speaker provides assistance in any discussion in which a language barrier might impede understanding of the more detailed concepts of $C B E$ or nursing education and curriculum development. The externally identified expertise provides additional support to a carefully selected team of Egyptian health professional educators who will develop the revised curriculum throughout the 4-year project. Engagement began in July 2017, with an initial series of workshops designed to equip the Egyptian project team with a clear understanding of $\mathrm{CBCs}$ in the field of technical/practical nursing education, and key steps involved in upgrading the existing curricula.

\section{Current curricula}

Many curricula in low- and middle-income nations remain based on earlier models of nursing education. Characteristics of earlier models include: didactic teaching styles, the nurse's role conceptualized as the doctor's "handmaiden", and adoption of apprenticeship hospital- and task-based models (28). The current structure of Egyptian curricula for technical nurses is consistent with 
Figure 1 Location of technical institutes in Egypt

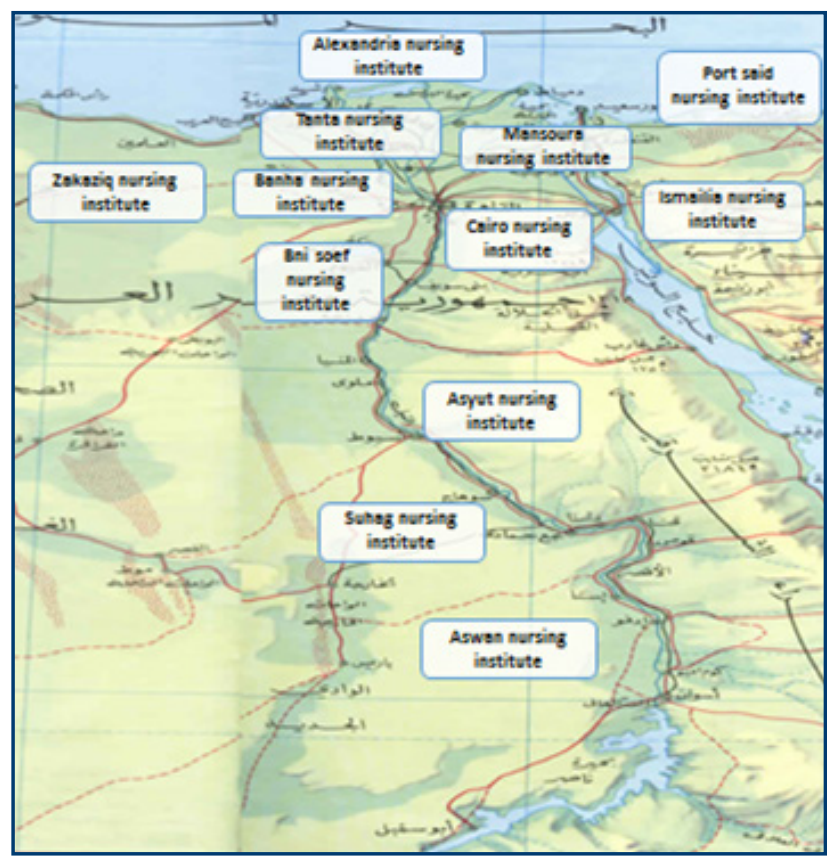

these characteristics (Table 1), with many subjects taught by medical rather than nursing staff. These curricula, designed for an earlier era, need redesigning to reflect the rapidly changing demographic landscape and healthcare needs (29).

\section{Three-stage project design}

The project involves three distinct stages over a 4-year period: 1) design phase of 9-12 months; 2) pilot/validation phase of 2.5 years; and 3) evaluation and sign-off for national rollout of the developed curriculum involving a 9-month implementation process (Figure 2). During the (current) 12-month curriculum design stage, MOHP and EDF leaders have engaged in global consultations, with particular consideration of nursing education standards defined by the European Union $(30,31)$. Partnerships with external experts, review of global standards, establishing a curriculum development team, curriculum development workshops, and stakeholder consultations provide a robust platform to support development of the contextually relevant $\mathrm{CBC}$ for technical-level nurses in Egypt. Conclusion of the design stage includes formal EDF sign-off on the curriculum model and content, and agreement to enter the pilot/validation stage. Validation will occur in three carefully selected institutes. The curriculum will be piloted in these institutes over the 2-year programme and 6-month internship cycle. Piloting of the new curriculum will occur closely with development of student admission, progression and completion policies, along with monitoring, evaluation, revision, regular feedback and internal/external audit of the education process. Lessons and findings from the design and pilot phases of the project will inform the approved curriculum for formal national rollout. Following approval, the project will enter the final stage and the new curriculum will be rolled out nationally across the 12 technical institutes. The mandate for accreditation and ongoing quality control will rest with relevant educational and professional quality assurance and accreditation agencies, such as the MoHP Nursing Syndicate and the National Authority of Educational Quality Assurance and Accreditation.

\section{Considerations in curriculum development and design}

A number of carefully sequenced considerations should inform the curriculum design process, including agreement on terminology, curriculum structure, content, and theory-to-practice considerations. Fit with Egyptian culture, context and identified health needs is equally important. It is envisaged that the final product will result in a curriculum focused on developing nursing competencies in both the art and science of nursing, promotion of health and prevention of illness, patient safety, education and advocacy, and supporting progression towards the United Nations Sustainable Development Goals (32).

\section{Defining competence and competency}

Multiple definitions of competence and competency exist with no apparent global consensus. Working definitions used in this project consider competence as a generic term reflecting a dynamic combination of knowledge/ understanding, skills and abilities, defined as a person's overall capacity to perform a given role, including both capability and performance, and involving observable/

\section{Table 1 Current curriculum content}

\section{Modules covered in the current technical nursing curriculum}

1. Nursing fundamentals
2. Maternal health and nursing
3. Paediatric medicine and nursing
4. Anatomy
5. Adult health nursing
6. Psychiatric nursing
7. Nursing management
8. Epidemiology
9. Pathophysiology
10. Pharmacology




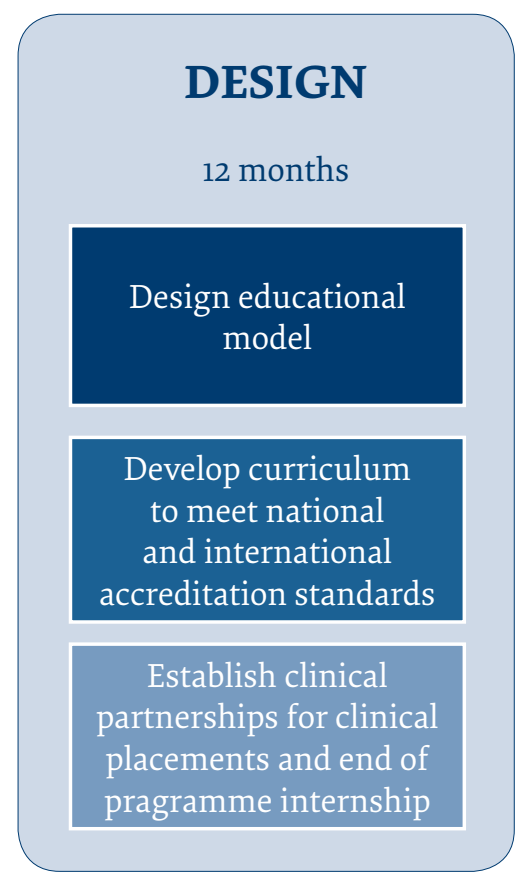

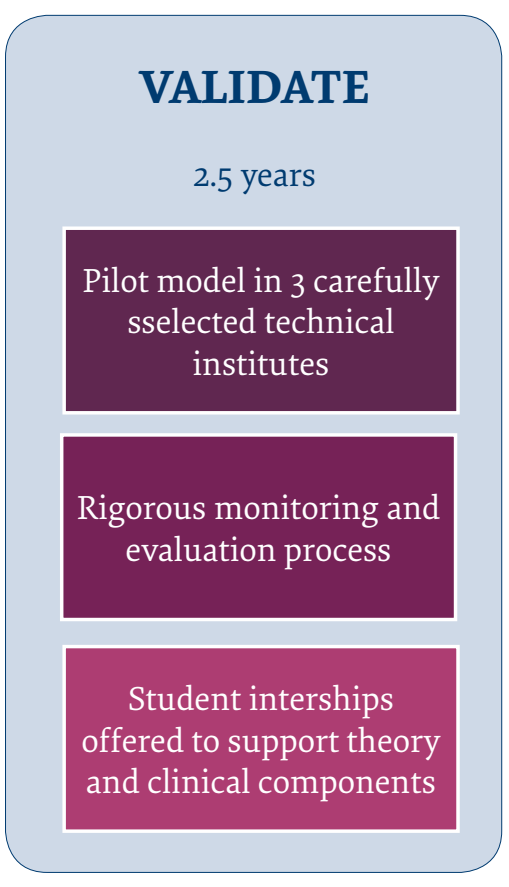

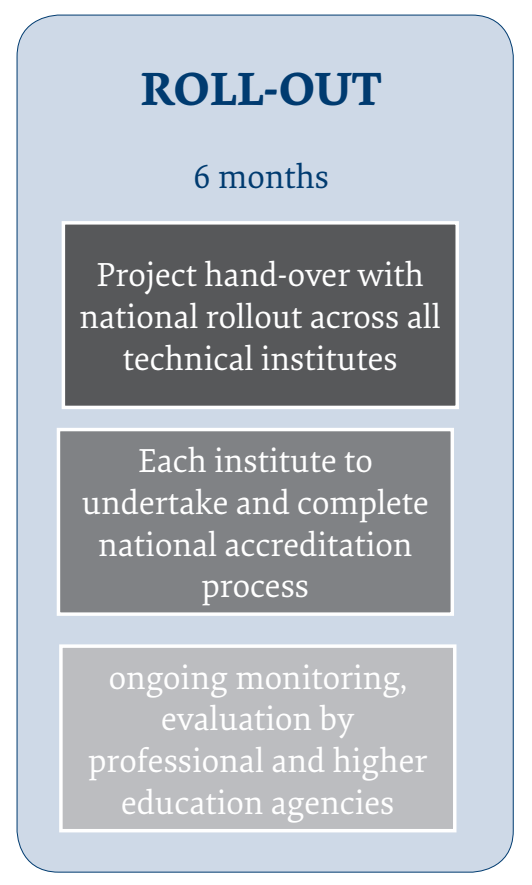

unobservable attributes (attitudes, values and judgment ability) (33). Competence reflects what it means to be a professional (34). Competency refers to an observable and measureable quality of a health professional that integrates multiple components (knowledge, skills, values and attitudes), and can be defined as the specific ability to perform work activities consistently to agreed standards over a range of contexts/conditions, and perform these tasks safely and effectively in a specific health workforce role (33). Competency describes a specific skill and competence the ability to perform that skill (34).

The International Bureau of Education defines $\mathrm{CBC}$ as a curriculum that "emphasizes the complex outcomes of a learning process (i.e., knowledge, skills and attitudes to be applied by learners) rather than focusing on what learners are expected to learn about in terms of traditionally defined subject content" (35). Another definition suggests that a CBC "incorporates modes of instruction and assessment efforts designed to evaluate mastery of learning by students through their demonstration of the knowledge, attitudes, values, skills and behaviours required for the degree sought" (36). CBCs should be learner-centred and adapt to changing needs of students, teachers and communities. Such curricula are designed around key competences/competencies, focusing on learning outcomes and graduate competencies and require demonstrated attainment of specific outcomes before progression (37).

\section{Global and regional guidelines and resources}

A number of globally and regionally developed guidelines and resources are available to the project team to guide curriculum development, including the National League of Nursing guide regarding graduate outcomes and competencies (38); the WHO Global Standards for Initial Preparation of Nurses and Midwives (39); and the European Standards for Nursing and Midwifery programmes (31). Further guidance is available by accessing the recently released curriculum prototypes for nursing and midwifery education published by the WHO Regional Office for Africa $(40,41)$. The recently developed patient safety framework for nursing students is of particular relevance to ensure the revised curriculum prepares graduates with competencies to address infection control and related patient safety issues (42). While these resources were useful, a key challenge was that they were primarily designed to guide degree-level nursing education. With the exception of the National League of Nursing resource, few resources are currently available to guide the development of second-level nursing education programmes.

\section{Moving towards CBE}

It is recognized that educational reform is difficult to achieve and successful implementation is slow. Changing to a competency-based model presents administrative challenges $(37,43)$. Such a change is more than a paper exercise of upgrading a written curriculum. It involves multiple aligned activities including: understanding differences between traditional curricula and CBCs; aligning developments with global standards in nursing education; basing learning on best practices in known educational theories; embedding culturally relevant models of care; supporting faculty development; and building partnerships for effective clinical learning environments (44). As highlighted, it is important to ensure alignment of new curricula with global standards while reflecting local culture, context and population health needs (37). 
Transitioning to CBCs resonates with Florence Nightingale's call for change $>150$ years ago, when she positioned nurses and nursing knowledge as greater than knowledge and technical skills alone. She challenged nurses to develop practice competencies focused on providing a safe and caring environment, doing no harm and advocating for patients, while promoting principles of egalitarianism and human rights, and demonstrating nursing leadership and critical thinking (45).

\section{Nursing role}

Changing social and political contexts and population characteristics nationally and globally have major implications for nursing. Nurses are increasingly recognised as partners in care. As the largest health professional grouping in the health sector, they have the capacity to influence health service outcomes (46). To maximise this potential, it is essential that the CBC in Egypt enables nurses to practice to full capacity. $C B C$ s engage learners with a focus on the competencies of critical thinking, leadership, problem solving, patient safety and ethical practice. Common themes in $\mathrm{CBC}$ development include designs that can be tailored to individual learners; enabling the development of clinical judgment and leadership capacity; and being based on achievement of competencies using evidence-based best practice and recognized approaches to teaching and learning, such as clinical simulation and self-directed and blended learning. $\mathrm{CBCs}$ also embrace adult learning principles and offer opportunities for relevant multidisciplinary content and learning experiences. Development of critical thinking is central to enhancing nursing roles and scaling up nursing workforce capacity: "The most important practical lesson that can be given to nurses is to teach them what to observe - how to observe - what symptoms indicate improvement - what the reverse - which are of importance - which are of none" (47). Given the current disease burden, enhanced nursing roles are essential, rather than a high level of reliance on doctors alone (48).

\section{Alignment with National Academic Reference Standards (NARS)}

Parallel to this project, Egypt has embarked on quality improvement initiatives across its health and education sectors, including developing NARS in various disciplines (including nursing). NARS for nursing (49) are designed for baccalaureate-level nurses. Launched in April 2017, they represent a first step toward a nationally approved scope of practice and standards for first-level registered nurses (RNs). These developments symbolize the response of the Egyptian government to increasing population expectations of consistent accountability and clarity with respect to competencies that can be expected from all health practitioners at all levels in the workforce. NARS nursing competencies are structured in five domains: professional and ethical practice; holistic patient-centred care; managing people, quality and work environment; informatics and technology; and interprofessional communication.
Development of a similar framework is needed for technical-level nurses; meantime, adopting a consistent framework across all levels of the nursing workforce will facilitate smoother career pathways for nurses aspiring to upgrade from technical- to BScN-level qualifications.

\section{Defining scope of practice for technical- level nurses}

Currently, Egypt does not have nationally agreed or published scopes of practice for the various cadres within the nursing workforce. Therefore, a clear starting point is identifying a range of global descriptions, standards and graduate outcomes for practical or second-level nurses compared with first-level RNs. Terminology used to describe this nursing workforce group differs around the world; for example, the American associate degree, the New Zealand and Australian enrolled nurse, and the UAE practical-level nurse. In addition, there are differences in the length of programmes for these nurses, with some being 3-year programmes that can bridge to a BScN. Despite these differences, the scope of practice is consistently outlined in similar ways across different regions, with second-level nurses described as being accountable for their own practice but working under the delegated authority of a fully qualified RN/first-level nurse, as illustrated by the following Australian example. "An enrolled nurse is a person who provides nursing care under the direct or indirect supervision of a registered nurse ... Enrolled nurses are accountable for their own practice and remain responsible to a registered nurse for the delegated care." (50).

An important first step for the curriculum team is to draft the scope of practice on which technical nurse graduate outcomes and competency-based expectations will be based. Global benchmarks from the USA, Australia and UAE will be sourced and aligned with the NARS domains. For example, the NARS competency, "provides holistic and evidence-based nursing care in different practice settings", resonates with requirements for UAE practical nurses, Australia/New Zealand enrolled nurses and American associate nurses. Although specific details of this domain differ across these countries, common elements include factors such as optimizing patient care and supporting patient involvement in care. Table 2 presents examples of NARS registered nurse competencies translated to technical-level practice.

\section{Importance of practice}

Global standards indicate that nursing education should include a minimum of $50 \%$ practice $(31,39)$. Immanuel Kant noted, "Experience without theory is blind, but theory without experience is mere intellectual play." (51). Kant's sentiment captures the importance of balancing theory and practice in professional nursing education, with both equally valued. Failure to achieve this balance risks producing graduates who do not understand their role or who are not sufficiently competent in providing nursing care. Worldwide, most nursing regulatory authorities provide guidance to education providers or have 
regulations setting out minimum requirements for theory and practice. Such guidelines are yet to be developed in Egypt. Logical next steps are defining a scope of practice and tightening regulations governing the balance of theory and practice, by specifying competency requirements and minimum numbers of hours, similar to the European model (30).

\section{Local flexibility}

The new curriculum is being developed with consideration of the local and national culture and context, including Egypt-specific population health considerations. While the curriculum will be defined nationally, each provider will have up to $20 \%$ flexibility to ensure contextualization at regional/local levels. An important consideration relates to suboptimal infection control measures, as demonstrated by high levels of hospital-acquired infections (including iatrogenically induced hepatitis B and C). Reported levels of medication errors and other safety indicators are out of alignment with international standards. For example, content such as the Joint Commission International patient safety goals (52) (Figure 3) becomes critical for integration in all modules.

Other considerations include the ethnic and religious backgrounds of the populations served across the 27 directorates in Egypt and associated urban, rural and geographic landscapes. Specific population health and education are key considerations as there are significant differences in population health needs, for example, between the Nubian communities of Upper Egypt and those in the urban centre of Alexandria at the mouth of the Nile. The Egyptian population includes differing religious groupings (e.g., Muslim and Coptic Christian). Consideration of various religious and secular models that reflect the diversity in Egypt may enhance cultural sensitivity and fit.

\section{Foundations of proven educational theory}

Basing the curriculum on proven educational theory is important to maximize learning and ensure achievement of desired graduate outcomes (53). Well-established educational concepts should be considered in developing $\mathrm{CBCs}$, including those described by theorists such as Bruner, Dewey and Vygotsky (54). These concepts describe approaches such as taking learners on a journey from the simple to complex, adoption of a curriculum allowing for continuous learning, reinforcing critical requirements such as adequate practice in the curriculum, and strengthening theory to practice links.

Vygotsky's zone of proximal learning and the process of taking the learner on a journey from the known to unknown or the simple to complex requires that the curriculum is structured in a systematic manner with increasing levels of difficulty. Bruner's spiral curriculum model, by which information is presented and revisited with increasing degrees of challenge and competency

\begin{tabular}{|c|c|}
\hline $\begin{array}{l}\text { Sample of NARS competencies: } \\
\text { registered nurses in Egypt [59] }\end{array}$ & $\begin{array}{l}\text { NARS-aligned draft competencies: } \\
\text { technical nurses in Egypt }{ }^{\mathrm{a}}\end{array}$ \\
\hline \multicolumn{2}{|l|}{ Domain 1: Professional and ethical practice } \\
\hline $\begin{array}{l}\text { Demonstrate knowledge, understanding, accountability, and } \\
\text { responsibility of the legal obligations for ethical nursing practice }\end{array}$ & $\begin{array}{l}\text { Demonstrate understanding of ethical nursing practice that } \\
\text { accountably translate to the ethical conduct of patient care with } \\
\text { responsibility for actions and omissions }\end{array}$ \\
\hline \multicolumn{2}{|l|}{ Domain 2: Holistic patient-centred care } \\
\hline $\begin{array}{l}\text { Provide holistic and evidence-based nursing care in different practice } \\
\text { settings }\end{array}$ & $\begin{array}{l}\text { Contribute to health education of patients/clients within a supervised } \\
\text { nursing framework }\end{array}$ \\
\hline \multicolumn{2}{|l|}{ Domain 3: Managing people, quality and work environment } \\
\hline $\begin{array}{l}\text { Provide a safe working environment that prevents harm for patients } \\
\text { and workers }\end{array}$ & $\begin{array}{l}\text { Contribute to the provision of a safe working environment to prevent } \\
\text { harm to patients and workers }\end{array}$ \\
\hline $\begin{array}{l}\text { Use a variety of sources to review outcomes and compare care with } \\
\text { benchmarks to achieve nursing care quality improvement }\end{array}$ & $\begin{array}{l}\text { Provide information and data to contribute to the review of outcomes } \\
\text { and assist benchmarking to achieve nursing care quality improvement }\end{array}$ \\
\hline \multicolumn{2}{|l|}{ Domain 4: Informatics and technology } \\
\hline $\begin{array}{l}\text { Use information and technology to underpin health care delivery, } \\
\text { communicate, manage knowledge, and support decision making for } \\
\text { patient care }\end{array}$ & $\begin{array}{l}\text { Contribute to the use of information and application of technology to } \\
\text { healthcare delivery, knowledge management, and decision support for } \\
\text { patients }\end{array}$ \\
\hline $\begin{array}{l}\text { Use information and communication technology in the delivery of } \\
\text { patient/client care }\end{array}$ & $\begin{array}{l}\text { Use information and communication technology in the delivery of } \\
\text { patient/client care, in defined areas of practice }\end{array}$ \\
\hline \multicolumn{2}{|l|}{ Domain 5: Interprofessional communication } \\
\hline $\begin{array}{l}\text { Collaborate with colleagues and members of the healthcare team to } \\
\text { facilitate and coordinate care provided for individuals, families and } \\
\text { communities }\end{array}$ & $\begin{array}{l}\text { With colleagues and members of the health care team, identify and } \\
\text { provide the nursing components of coordinated care for individuals, } \\
\text { families and communities }\end{array}$ \\
\hline
\end{tabular}

${ }^{a}$ Drafted by curriculum development workshop participants as a suitability aligned equivalent to the NARS standards for registered nurses.

NARS = National Academic Reference Standards. 
Figure 3 International patient safety goals

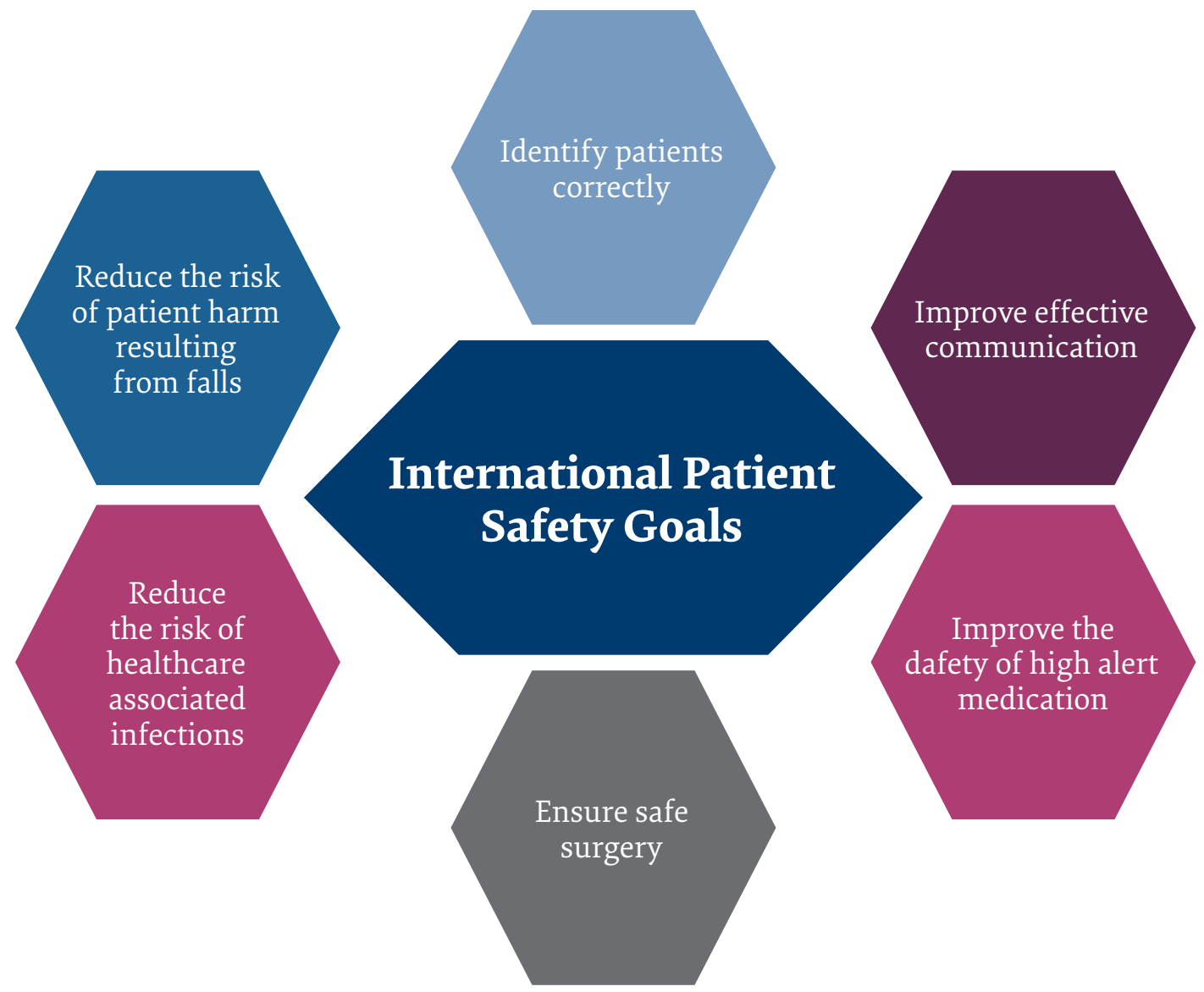

requirements, allows for a cycle of continuous learning until the learner has grasped and mastered the full complexity of the concept or skill (55). Dewey's concept of learning by doing reinforces the critical requirement for adequate practice within the curriculum, along with sequencing styles to strengthen theory to practice links (56).

\section{Contemporary teaching and learning approaches}

Successful implementation of a $\mathrm{CBC}$ requires different teaching and learning techniques. $\mathrm{CBE}$ demands movement away from teaching dominated by lectures, PowerPoint presentations and didactic instruction. Changes in clinical instruction are essential with the requirement to move from time-based didactic strategies to focus on the acquisition of skills and competencies and achievement of clear learning outcomes $(44,57,58)$. Therefore, success is dependent on parallel investments in faculty development focused on new pedagogical approaches.

\section{Conclusions}

The Egyptian constitutional commitment to every citizen of the right to health is advancing by various strategies, including capacity development of the technical-level nursing education system and associated nursing workforce. Success is dependent on the recognition that such processes require both time and resources, and start with reform of the educational model and curricula by which the nursing workforce is prepared. The project described in this paper represents the pragmatic and realistically incremental approach of the EDF to curriculum design, validation and rollout, designed to increase the likely effectiveness of the challenging process of educational reform. Combined with detailed attention to identified curriculum development considerations, the project is poised to be a major enabler in strengthening the cadre of technical-level nurses in Egypt.

Funding: None.

Competing interests: None declared. 


\section{Développement d'un programme d'enseignement national fondé sur les compétences pour les infirmiers techniciens en Égypte}

\section{Résumé}

La profession infirmière en Égypte a évolué au cours des dernières décennies. Son développement s'est accéléré suite à la reconnaissance récente par le gouvernement de la contribution apportée par les personnels infirmiers à l'accessibilité, la qualité et la prestation des services de santé. Un projet visant à renforcer les capacités des personnels infirmiers a débouché, récemment, sur un nouveau mandat exigeant que tous les programmes d'enseignement en soins infirmiers soient fondés sur les compétences. Dans le même temps, le Fonds de développement pour l'éducation du Cabinet des ministres égyptien a rédigé un plan pour l'enseignement des soins infirmiers comprenant une stratégie dont le but est d'élaborer et de mettre en œuvre un modèle d'éducation contextuellement cohérent, ayant fait ses preuves et d'un niveau comparable aux normes internationales. Le présent article examine le projet d'élaboration de ce programme d'enseignement, d'une durée de quatre ans, destiné à améliorer le programme actuel suivi par les infirmiers techniciens et à le transformer en un modèle cohérent fondé sur les compétences. Ce modèle d'éducation fondé sur les compétences fera l'objet d'un essai au sein de trois instituts techniques avant d'être déployé et mis en œuvre au niveau national. Les détails de la structure du projet sont décrits, avec notamment un aperçu des considérations liées à l'élaboration du programme d'enseignement. Le présent article fournit des idées utiles aux décideurs politiques et aux enseignants qui entreprennent des réformes semblables de leurs personnels de santé ainsi que des initiatives de renforcement des capacités.

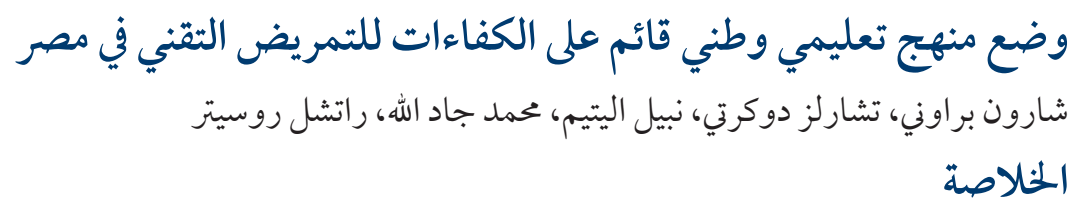

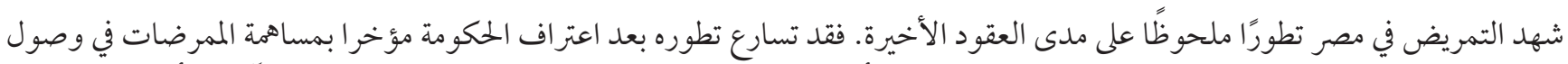

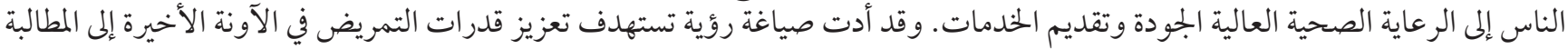

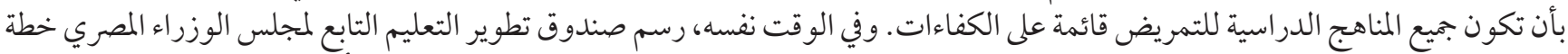

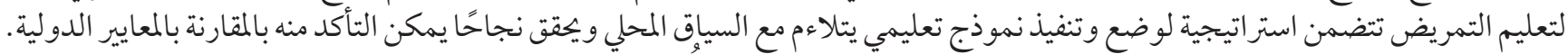

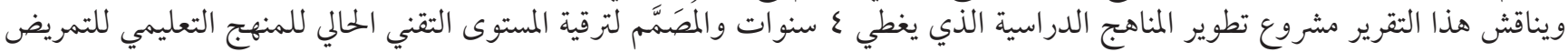

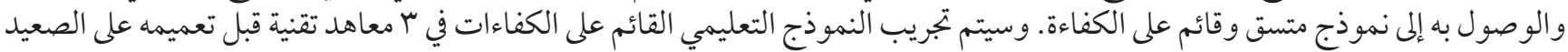

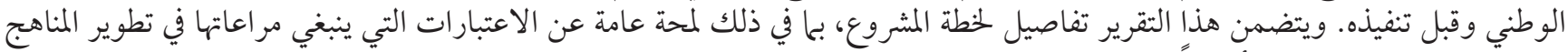

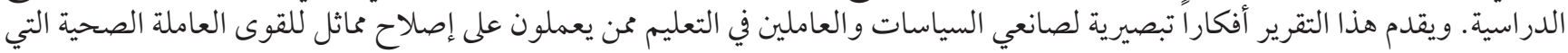
تماثل التمريض، وفي مبادرات تطوير القدرات.

\section{References}

1. Worldometers. Egypt population (live) [website] (http://www.worldometers.info/world-population/egypt-population, accessed 11 June 2018).

2. World Health Organization. Eastern Mediterranean Health indicators. Regional Office for the Eastern Mediterranean; 2015.

3. Nankervis K, Kenny A, Bish M. Enhancing scope of practice for the second level nurse: a change process to meet growing demand for rural health services. Contemp Nurse. 2008 Jun;29(2):159-73. https://doi.org/10.5172/conu.673.29.2.159 PMID:18844530

4. Nightingale College. RN to BSN guides. The real differences between ADN and BSN nurses [website] (http://nightingale.edu/ blog/adn-vs-bsn-differences/, accessed 11 June 2018).

5. Nursing and Midwifery Board of Australia. Fact sheet: enrolled nurse standards for practice [website]. AHPRA; 2018 (http://www. nursingmidwiferyboard.gov.au/Codes-Guidelines-Statements/FAQ/Enrolled-nurse-standards-for-practice.aspx, accessed 11 June 2018).

6. Nursing and Midwifery Board of Australia. Fact sheet: enrolled nurses and medicine administration [website]. AHPRA; 2018 (http://www.nursingmidwiferyboard.gov.au/Codes-Guidelines-Statements/FAQ/Enrolled-nurses-and-medicine-administration. aspx, accessed 11 June 2018).

7. Health Authority Abu Dhabi. Policy scope of practice for practical nurse. 2012 (https://www.haad.ae/HAAD/LinkClick.aspx?fileticket=XA1Yvh1_90Q\%3D\&tabid=819, accessed 11 June 2018).

8. World Health Organization Country Office for Egypt. Egypt nursing profile. Cairo: World Health Organization; 2012 (http://www. emro.who.int/images/stories/cah/fact_sheet/Nursing_Profile.pdf, accessed 11 June 2018).

9. Ma C, Fouly H, Li J, D’Antonio P. The education of nurses in China and Egypt. Nurs Outlook. 2012 May-Jun;60(3):127-133.e1. https://doi.org/10.1016/j.outlook.2011.08.002 PMID:22000692 
10. Global Health Observatory (GHO) data. Density of nursing and midwifery personnel (total number per 10oo population, latest available year) [website]. Global Health Observatory, World Health Organization; 2017 World Health Organization; 2018 (http:// www.who.int/gho/health_workforce/nursing_midwifery_density/en/, accessed 11 June 2018)

11. Khaled A. Egypt: Ailing nursing colleges promised rescue. University World News, Africa Edition. 16 January 2011 (http://www. universityworldnews.com/article.php?story=20110114223638291, accessed 11 June 2018).

12. Bhutta ZA, Chen L, Cohen J, Crisp N, Evans T, Fineberg H, et al. Education of health professionals for the 21st century: a global independent Commission. Lancet. 2010 Apr 3;375(9721):1137-8. https://doi.org/10.1016/So140-6736(10)60450-3 PMID:20362799

13. Nicholas PK, Corless IB, Fulmer H, Meedzan N. Preparing nursing students for education in the global village. MCN Am J Matern Child Nurs. 2012 Nov-Dec;37(6):367-72. https://doi.org/10.1097/NMC.obo13e318258age1 PMID:23073249

14. Technical Institutes Directorate. Overview of nursing in Egypt. Cairo: Ministry of Health and Population; 2017.

15. Pande A, El Shalakani A, Hamed A. How can we measure progress on social justice in health care? The case of Egypt. Health Syst Reform. 2017;3(1):14-25. https://doi.org/10.1080/23288604.2016.1272981

16. Violence against children in Egypt. Quantitative survey and qualitative study in Cairo, Alexandria and Assiut. Cairo: National Council for Childhood and Motherhood; United Nations Children's Fund, Egypt; 2015 (https://www.unicef.org/mena/sites/unicef. org.mena/files/press-releases/mena-media-Violence_Against_Children_in_Egypt_study_Eng-UNICEF_NCCM_1002015.pdf, accessed 11 June 2018).

17. World Health Organization. Countries: Egypt [website]. World Health Organization; 2018 (http://www.who.int/countries/egy/en/, accessed 11 June 2018).

18. Elgharably A, Gomaa AI, Crossey MM, Norsworthy PJ, Waked I, Taylor-Robinson SD. Hepatitis C in Egypt - past, present, and future. Int J Gen Med. 2016 Dec 20;10:1-6. https://doi.org/10.2147/IJGM.S119301 PMID:28053553

19. Patient safety assessment manual. Second edition. World Health Organization Regional Office for the Eastern Mediterranean; 2016 (http://apps.who.int/iris/bitstream/handle/10665/249569/EMROPUB_2016_EN_18948.pdf?sequence=1\&isAllowed=y, accessed 11 June 2018).

20. Report on the burden of endemic health care-associated infection worldwide. Geneva: World Health Organization; 2011 (http:// apps.who.int/iris/bitstream/handle/10665/80135/9789241501507_eng.pdf?sequence=1, accessed 11 June 2018).

21. Elmaghloub R, Elbahrawy A, El Didamony G, Hashim A, Morsy MH, Hantour O, et al. Occult hepatitis B infection in Egyptian health care workers. East Mediterr Health J. 2017 Jul 16;23(5):329-34. https://doi.org/10.26719/2017.23.5.329 PMID:28730585

22. Haugen AS, Murugesh S, Haaverstad R, Eide GE, Søfteland E. A survey of surgical team members' perceptions of near misses and attitudes towards Time Out protocols. BMC Surg. 2013 Oct 9;13(1):46. https://doi.org/10.1186/1471-2482-13-46 PMID:24106792

23. Boutayeb A, Helmert U. Social inequalities, regional disparities and health inequity in North African countries. Int $J$ Equity Health. 2011 May 31;10(1):23. https://doi.org/10.1186/1475-9276-10-23 PMID:21627818

24. Egypt's Constitution of 2014 (https://issafrica.org/ctafrica/uploads/EgyptConstitution2014Eng.pdf, accessed 11 June 2018).

25. Gadallah MH. Competency-based nursing education. Cairo: Education Development Fund, The Cabinet of Ministers; 2017.

26. Andronache D, Bocoş M, Neculau B. A systemic-interactionist model to design a competency-based curriculum. Procedia Soc Behav Sci. 2015;180:715-21. https://doi.org/10.1016/j.sbspro.2015.02.183

27. Aga Khan University [website]. 2018 (https://www.aku.edu/Pages/home.aspx, accessed 11 June 2018).

28. Scheckel M. Nursing education: Past, present, future. In: Halstead GRJ, editor. Issues and trends in nursing: Essential knowledge for today and tomorrow. Burlington (MA): Jones and Bartlett; 2009: 27-60.

29. Botma Y. Implications of accreditation criteria when transforming a traditional nursing curriculum to a competency-based curriculum. Int J Africa Nurs Sci. 2014;1:23-8. https://doi.org/10.1016/j.ijans.2014.06.002

30. Palese A, Zabalegui A, Sigurdardottir AK, Bergin M, Dobrowolska B, Gasser C, et al. Bologna process, more or less: nursing education in the European economic area: a discussion paper. Int J Nurs Educ Scholarsh. 2014 Apr 2;11(1):63-73. https://doi.org/10.1515/ ijnes-2013-0022 PMID:24695045

31. European Union standards for nursing and midwifery: information for accession countries. Second edition. Copenhagen: World Health Organization Regional Office for Europe; 2009 (http://www.euro.who.int/_data/assets/pdf_file/0005/102200/E92852. pdf?ua=1, accessed 11 June 2018).

32. Sustainable Development Goals [website] United Nations Development Programme; 2018 (http://www.undp.org/content/undp/ en/home/sustainable-development-goals/background.html, accessed 11June 2018).

33. Brownie S, Bahnisch M, Thomas J. Exploring the literature: competency-based education and competency-based career frameworks: deliverable fulfilling part of the requirements for NHPRC Projects 4 and 5 regarding frameworks for competency-based education, training and health career frameworks. Adelaide: University of Queensland Node of the Australian Health Workforce Institute in partnership with Health Workforce Australia; 2011.

34. Pijl-Zieber EM, Barton S, Konkin J, Awosoga O, Caine V. Competence and competency-based nursing education: finding our way through the issues. Nurse Educ Today. 2014 May;34(5):676-8. https://doi.org/10.1016/j.nedt.2013.09.007 PMID:24090616

35. Competency-based curriculum. Geneva: International Bureau of Education. (http://www.ibe.unesco.org/en/glossary-curriculum-terminology/c/competency-based-curriculum, accessed 11 June 2018). 
36. Gervais J. The operational definition of competency-based education. J Competency-based Educ. 2016;1(2):98-106. https://doi. org/10.1002/cbe2.1011

37. Gravina J. Competency-based education and its effect on nursing education. Teach Learn Nurs. 2017;12(2):117-21. https://doi. org/10.1016/j.teln.2016.11.004

38. Outcomes and competencies for graduates of practical/vocational, diploma, baccalaureate, master's practice doctorate, and research doctorate programs in nursing. Washington (DC): National League of Nursing; 2012.

39. Global standards for the initial education of professional nurses and midwives. Geneva, Switzerland: World Health Organization; 2009 (http://www.who.int/hrh/nursing_midwifery/hrh_global_standards_education.pdf, accessed 11 June 2018).

40. World Health Organization Regional Office for Africa. Four-year integrated nursing and midwifery competency-based curriculum. Prototype curriculum for the Africa Region. Brazzaville, Congo: World Health Organization; 2016.

41. Three year regional prototype pre-service competency-based nursing curriculum. Brazzaville: World Health Organization Regional Office for Africa; 2016 (http://apps.who.int/iris/bitstream/handle/10665/254742/9789290232612-eng.pdf?sequence=1\&isAllowed=y, accessed 11 June 2018).

42. Levett-Jones T, Dwyer T, Reid-Searl K, Heaton L, Flenady T, Applegarth J, et al. The patient safety competency framework for nursing students. (http://www.proftlj.com/wp-content/uploads/2017/07/UTS_PSCF_Brochure_2.pdf, accessed 11 June 2018).

43. Frenk J, Chen L, Bhutta ZA, Cohen J, Crisp N, Evans T, et al. Health professionals for a new century: transforming education to strengthen health systems in an interdependent world. Lancet. 2010 Dec 4;376(9756):1923-58. https://doi.org/10.1016/So1406736(10)61854-5 PMID:21112623

44. Wilson KD, Wood SJ, Embry E, Wright KS. Using a community-based participatory research approach to create a competency based health systems strengthening curriculum in a developing country. J Health Adm Educ. 2016;31(1):121-40.

45. Selanders LC, Crane PC. The voice of Florence Nightingale on advocacy. Online J Issues Nurs. 2012 Jan 31;17(1):1. PMID:22320877

46. Brownie S, Hills AP, Rossiter R. Public health service options for affordable and accessible noncommunicable disease and related chronic disease prevention and management. J Multidiscip Healthc. 2014 Nov 24;7:543-9. https://doi.org/10.2147/JMDH.S72636 PMID:25473294

47. Brainy Quote. Florence Nightingale quotes [website]. (https://www.brainyquote.com/quotes/authors/f/florence_nightingale.html, accessed 11 June 2018).

48. De Maeseneer J, Roberts RG, Demarzo M, Heath I, Sewankambo N, Kidd MR, et al. Tackling NCDs: a different approach is needed. Lancet. 2012 May 19;379(9829):1860-1. https://doi.org/10.1016/So140-6736(11)61135-5 PMID:21899880

49. National Academic Reference Standards (NARS) Nursing. Egypt: National Authority for Quality Assurance and Accreditation of Education; 2009 (http://naqaae.eg/wp-content/uploads/2014/PDF/3.pdf, accessed 11 June 2018).

50. Registered nurse standards for practice. Nursing and Midwifery Board of Australia; 2016 (http://www.nursingmidwiferyboard. gov.au/Codes-Guidelines-Statements/Professional-standards/registered-nurse-standards-for-practice.aspx, accessed 11 June 2018).

51. Luchte J. Kant's critique of pure reason. London: Bloomsbury; 2007.

52. International patient safety goals [website] Joint Commission International. (http://www.jointcommissioninternational.org/ improve/international-patient-safety-goals/, accessed 11 June 2018).

53. Kabita DN, Ji L. The why, what and how of competency-based curriculum reforms: the Kenyan experience (Vol. 11). United Nations Educational, Scientific and Cultural Organization; International Bureau of Education; 2017 (http://unesdoc.unesco.org/ images/0025/002504/250431e.pdf, accessed 11 June 2018).

54. Chambers D, Thiekötter A, Chambers L. Preparing student nurses for ontemporary practice: The case for discovery learning. J Nurs Educ Pract. 2013;3(9):106-13. https://doi.org/10.5430/jnep.v3n9p106

55. Teachthought. Learning theories: Jerome Bruner on the scaffolding of learning 2014 (https://www.teachthought.com/learning/ learning-theories-jerome-bruner-scaffolding-learning/, accessed 11 June 2018).

56. Reese H. The learning-by-doing principle. Behav Dev Bull. 2011;17(1):1-19. https://doi.org/10.1037/ho100597

57. Muraraneza C, Mtshali NG, Mukamana D. Issues and challenges of curriculum reform to competency-based curricula in Africa: A meta-synthesis. Nurs Health Sci. 2017 Mar;19(1):5-12. https://doi.org/10.1111/nhs.12316 PMID:27805792

58. Gauthier RF. The competency-based approach to curriculum reform in five African countries: what can we learn from the 2008-2009 evaluation? Prospects. 2013;43(4):429-39. https://doi.org/10.1007/s11125-013-9289-3 